\title{
ELECTRICAL CONDUCTION BEHAVIOUR OF PVP BASED COMPOSITE POLYMER ELECTROLYTES
}

\author{
SK. Shahenoor Basha ${ }^{1}$, G. Sunita Sundari ${ }^{1}$, K. Vijay Kumar ${ }^{2}$, \\ K. Veera Bhadra Reddy ${ }^{3}$ and M.C. Rao ${ }^{*}$ \\ ${ }^{1}$ Solid State Ionics Laboratory, Department of Physics, K. L. University, Guntur - 522502, India \\ ${ }^{2}$ Department of Physics, Dayananda Sagar Academy of Technology and Management, \\ Udayapura, Bangalore-560 082, India \\ ${ }^{3}$ Department of Physics, NRI Institute of Technology, Vijayawada Rural-520010, \\ Krishna District, India \\ ${ }^{4}$ Department of Physics, Andhra Loyola College, Vijayawada- 520008, India \\ *E-mail:raomc72@gmail.com
}

\begin{abstract}
Solid state polymer electrolyte of $\mathrm{Mg}^{2+}$ was prepared by doping nano-sized $\mathrm{Al}_{2} \mathrm{O}_{3}$ particles on PVP complexed with $\mathrm{MgCl}_{2} \cdot 6 \mathrm{H}_{2} \mathrm{O}$ salt by solution cast technique. Electrical conductivity and dielectric properties have been carried-out on to the prepared polymer films. It was found that the conductivity of nano-sized $\mathrm{Al}_{2} \mathrm{O}_{3}$ doped PVP based solid polymer electrolyte was found to be $1.22 \times 10^{-6} \mathrm{~S} / \mathrm{cm}$ at room temperature for $85: 15$ compositions having low activation energy. Dielectric studies were carried-out for the prepared samples on HIOKI 3532-50 LCR Heister Range $42 \mathrm{~Hz}-5 \mathrm{MHz}$. It is observed that magnitude of dielectric permittivity is high in the lower frequency region due to electrode polarization (EP) effect. The dielectric permittivity and loss were increased with increase of temperature.
\end{abstract}

Keywords: PVP electrolyte, A.C. Conductivity, Activation energy and Dielectric properties.

(C) RASĀYAN. All rights reserved

\section{INTRODUCTION}

The development of polymer systems with high ionic conductivity is one of the main objectives in polymer research. This is because of their potential applications as electrolytes in solid-state batteries, fuel cells, electrochemical display devices/smart windows, photo- electrochemical cells etc. ${ }^{1-3}$, due to their high conductivity, high energy density, wide electrochemical stability and easy processibility. Intrinsically conducting polymers have attracted the attention of researchers because of their numerous applications $s^{4,5}$. In recent years tremendous effort has been made in the preparation of solid polymer electrolytes. The recent research trends in the field of rechargeable lithium batteries are directed towards the development of cells with high-energy density $(\mathrm{Wh} / \mathrm{kg})$ and high-power density. A primary work in the field of solid polymer electrolyte has been carried by Wright et al. ${ }^{6,7}$ and found that the ionic conductivity is of the order of $10^{-5} \mathrm{~S} / \mathrm{cm}$ at $330 \mathrm{~K}$ in PEO and NaSCN complexes.

A wide range of interest has been focused to prepare solid polymer electrolytes over a few decades due to their potential applications as electrolyte materials in high energy density batteries, rechargeable batteries and solid state batteries ${ }^{8,9}$. Magnesium is used as the excellent material for anode in solid state batteries which is naturally available in earth crust, in addition magnesium based devices are much cheaper than lithium devices, whereas magnesium is less reactive, non-toxic than the lithium in ambient temperatures and atmospheric conditions. So magnesium is used instead of lithium for solid state battery application ${ }^{10}$. The order of conductivity of pure polyvinyl pyrollodine (PVP) is found to be in the range from $10^{-9}$ to $10^{-7}$ $\mathrm{S} / \mathrm{cm}$ at room temperature and it is not suitable for battery applications. The order of ionic conductivity was improved from $10^{-7}$ to $10^{-5} \mathrm{~S} / \mathrm{cm}$ by the addition of nanoparticles of alumina $\left(\mathrm{Al}_{2} \mathrm{O}_{3}\right)$ with $\mathrm{MgCl}_{2} \cdot 6 \mathrm{H}_{2} \mathrm{O}$ in solid polymer electrolyte. Gregory et al. ${ }^{11}$ reported the electrochemical reversible 
deposition and dissolution process in $\left(\mathrm{Mg} \mathrm{Bph}_{2} \mathrm{Bu}_{2}\right)_{2}$, where polyvinyl pyrrolidone (PVP) has played major role in displaying dissolubility, stability, high-dielectric constant and compatibility.

PVP is soluble in polar solvents as well as ionized water and also PVP acts as thermally stable and cross linked with the composites and having high mechanical strength. PVP is chosen because it is having good mechanical, electrical and optical characteristics. Pyrrolidone group of PVP prefers to incorporate with organic and inorganic salts resulting in the formation of film which has good dispersion and surface formation $^{12}$. Solid polymer electrolyte complexed with inorganic salt and nanofillers/plasticizers were first introduced by Weston and Steele in $1982^{13}$. The addition of the fillers in the solid polymer electrolytes improves the electrical and mechanical strengths of the polymer ${ }^{14}$. Rao et al. published their results on different materials in the earlier studies ${ }^{15-68}$.

In the present work, solid polymer electrolyte films were prepared by adding $\mathrm{Al}_{2} \mathrm{O}_{3}$ particles to PVP$\mathrm{MgCl}_{2} \cdot 6 \mathrm{H}_{2} \mathrm{O}$. The purpose of this work is to improve the ionic conductivity by comparing with the other polymer electrolytes. The obtained results demonstrated that the electrical conductivity was improved by adding $\mathrm{Al}_{2} \mathrm{O}_{3}$ in $\mathrm{PVP}-\mathrm{MgCl}_{2} \cdot 6 \mathrm{H}_{2} \mathrm{O}$ for $85: 15$ compositions.

\section{EXPERIMENTAL}

Sigma Aldrich chemicals based PVP solid polymer electrolyte films doped with pure magnesium chloride hexahydrate and $\mathrm{Al}_{2} \mathrm{O}_{3}$ nanoparticles were dispersed in the different ratios (95:5), (90:10), (85:15) and (80:20) by using solution casting technique and double sterilized water is used as a solvent. The mixture of these solutions was stirred for 24 hours to obtain a homogeneoussolution. Later the nanocomposite polymer solution was placed in the polypropylene dishes and placed in a hot air oven at $60^{\circ} \mathrm{C}$ to remove the solvent trace in the polymer films. Later the films were taken off from the dishes and then placed in a desiccator until further test. The electrical conductivity, dielectric spectroscopy and impedance analysis studies were carried-out by using HIOKI 3532-50 LCR Heister in the frequency range from $42 \mathrm{~Hz}$ to $5 \mathrm{MHz}$ at room temperature (303K).

\section{A.C. Conductivity Studies}

\section{RESULTS AND DISCUSSION}

Figure-1 represents the Cole-Cole plot of prepared solid polymer electrolyte samples for different concentrations. Complex impedance plot shows a semi-circular arc at high frequency region and a spike shows at the low frequency region. A broadened semicircle is obtained due to a frequency-dependent capacitor $\left(\mathrm{C}_{\mathrm{g}}\right)$ parallel to the bulk resistor. The point where the semicircle intersects the real axis gives the value of the bulk resistance $\left(\mathrm{R}_{\mathrm{b}}\right)$.

The conductivity spectra of nanocomposite polymer electrolytes consist of low-frequency dispersive region at room temperature, which results the majority charge carriers flow in the solid polymer electrolyte is mostly due to ions and hence conductivity increases. This can be explained on the basis of the relaxation process ${ }^{69}$. Due to the good contact between electrode-electrolyte interfaces an electrode polarization phenomenon occurs. The Cole-Cole plot is obtained from the real part $\left(\mathrm{Z}^{\mathrm{I}}\right)$ vs an imaginary part $\left(\mathrm{Z}^{\mathrm{II}}\right)$ and the ionic conductivity is calculated by using the relation:

$$
\sigma_{\mathrm{ac}}=\mathrm{t} /\left(\mathrm{R}_{\mathrm{b}} \mathrm{X} A\right)
$$

Where, " $\mathrm{R}_{\mathrm{b}}$ " is the bulk resistance, " $\mathrm{t}$ " is the thickness of the solid polymer electrolyte and A is the area of the electrode. The calculated values of A.C. conductivity are shown in Table-1.

Table-1: A.C. conductivity values for various compositions of polymer films

\begin{tabular}{c|c}
\hline A.C. Conductivity values of $\left(\mathrm{PVP}+\mathrm{MgCl}_{2} \cdot 6 \mathrm{H}_{2} \mathrm{O}+\mathrm{Al}_{2} \mathrm{O}_{3}\right)$ Polymer electrolyte system \\
\hline Films & Conductivity at room temperature \\
\hline Pure PVP & $2.32 \times 10^{-9}(\mathrm{~S} / \mathrm{cm})$ \\
\hline
\end{tabular}


RASĀYAN J. Chem.

Vol. 10 | No. 1 |279 -285 | January - March | 2017

\begin{tabular}{c|c}
\hline $\mathrm{PVP}+\mathrm{MgCl}_{2} \cdot 6 \mathrm{H}_{2} \mathrm{O}+\mathrm{Al}_{2} \mathrm{O}_{3}(95: 5)$ & $2.32 \times 10^{-8}(\mathrm{~S} / \mathrm{cm})$ \\
\hline $\mathrm{PVP}+\mathrm{MgCl}_{2} \cdot 6 \mathrm{H}_{2} \mathrm{O}+\mathrm{Al}_{2} \mathrm{O}_{3}(90: 10)$ & $5.81 \times 10^{-7}(\mathrm{~S} / \mathrm{cm})$ \\
\hline $\mathrm{PVP}+\mathrm{MgCl}_{2} \cdot 6 \mathrm{H}_{2} \mathrm{O}+\mathrm{Al}_{2} \mathrm{O}_{3}(85: 15)$ & $1.22 \times 10^{-6}(\mathrm{~S} / \mathrm{cm})$ \\
\hline $\mathrm{PVP}+\mathrm{MgCl}_{2} \cdot 6 \mathrm{H}_{2} \mathrm{O}+\mathrm{Al}_{2} \mathrm{O}_{3}(80: 20)$ & $3.01 \times 10^{-6}(\mathrm{~S} / \mathrm{cm})$ \\
\hline
\end{tabular}

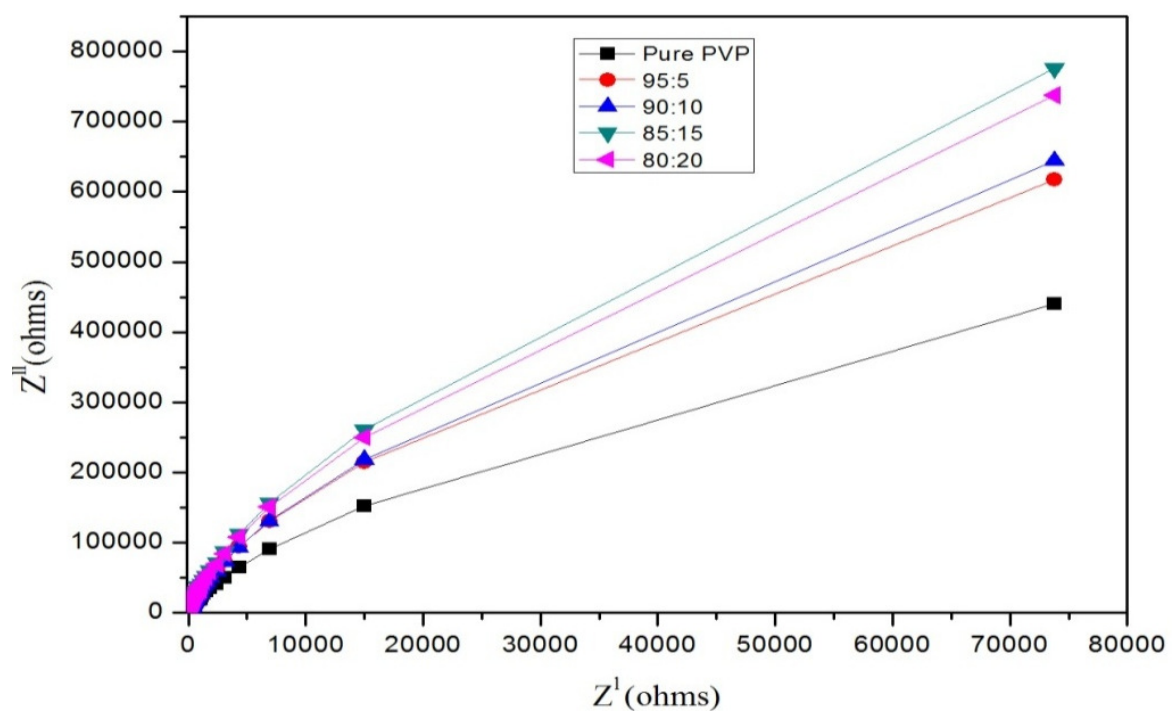

Fig.-1: Cole-Cole plots of (a) Pure PVP; (b) $\mathrm{PVP}+\mathrm{MgCl}_{2} \cdot 6 \mathrm{H}_{2} \mathrm{O}+\mathrm{Al}_{2} \mathrm{O}_{3}$ (95:5); (c) $\mathrm{PVP}+\mathrm{MgCl}_{2} \cdot 6 \mathrm{H}_{2} \mathrm{O}+\mathrm{Al}_{2} \mathrm{O}_{3}(90: 10$ );

(d) $\mathrm{PVP}+\mathrm{MgCl}_{2} \cdot 6 \mathrm{H}_{2} \mathrm{O}+\mathrm{Al}_{2} \mathrm{O}_{3}(85: 15)$; (e) $\mathrm{PVP}+\mathrm{MgCl}_{2} \cdot 6 \mathrm{H}_{2} \mathrm{O}+\mathrm{Al}_{2} \mathrm{O}_{3}(80: 20)$

\section{Activation energy studies}

Figure- 2 shows the decreasing of activation energy with the increase of the salt concentration. This may be due to the fact that the addition of small amount of dopant forms charges complexes in the host lattice $^{70}$, which results in a decrease of activation energy. The activation energy values for solid polymer electrolytes are given in Table-2.

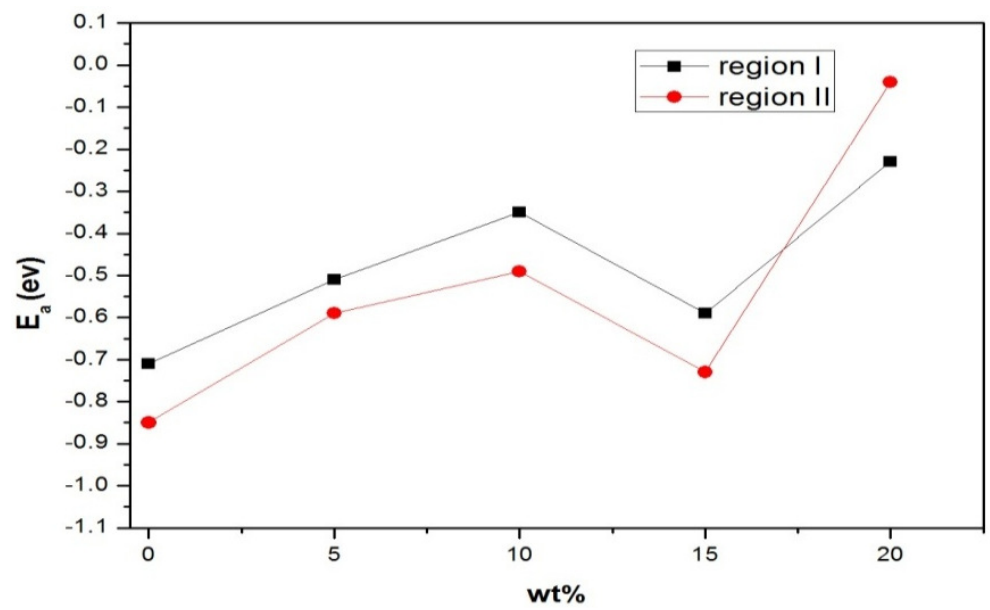

Fig.-2: Activation energy studies of (a) Region I (b) Region II

\section{Dielectric Properties}

The dielectric spectroscopy, impedance analysis studies were carried out by using HIOKI 3532-50 LCR Heister in the frequency range from $42 \mathrm{~Hz}$ to $5 \mathrm{MHz}$ at room temperature. The conductivity of the sample and the obtained data was analyzed. Figure- 3 and Figure- 4 show the dielectric constant is a measure of amount of charge stored. As increasing the frequency the dielectric constant values are gradually decreases and found to be high for the sample of $15 \mathrm{wt} \%$; this concludes that the drifting of ions is high giving raise to conductivity phenomenon. This reveals that the salt is completely dissolute in the polymer 
RASĀYAN $J$. Chem.

Vol. 10 | No. 1 |279-285 | January - March | 2017

chains giving raise to mobile ions. Due to the formation of space charge region at the electrode and electrolyte interfaces a variation is observed in between dielectric constant of $\varepsilon^{1}$ and $\varepsilon^{11}$ as increasing of frequency this behavior is known as non-Debye behavior. ${ }^{71,72}$

Table-2: Energy band gap values for various compositions of polymer films

\begin{tabular}{c|c|c}
\hline \multicolumn{3}{c}{$\begin{array}{c}\left.\text { Activation energy values of (PVP+ } \mathrm{MgCl}_{2} \cdot 6 \mathrm{H}_{2} \mathrm{O}+\mathrm{Al}_{2} \mathrm{O}_{3}\right) \text { Polymer } \\
\text { electrolyte system }\end{array}$} \\
\hline Films & Region 1 & Region 2 \\
\hline Pure PVP & 0.85 & 0.71 \\
\hline $\mathrm{PVP}+\mathrm{MgCl}_{2} \cdot 6 \mathrm{H}_{2} \mathrm{O}+\mathrm{Al}_{2} \mathrm{O}_{3}(95: 5)$ & 0.59 & 0.51 \\
\hline $\mathrm{PVP}+\mathrm{MgCl}_{2} \cdot 6 \mathrm{H}_{2} \mathrm{O}+\mathrm{Al}_{2} \mathrm{O}_{3}(90: 10)$ & 0.49 & 0.35 \\
\hline $\mathrm{PVP}+\mathrm{MgCl}_{2} \cdot 6 \mathrm{H}_{2} \mathrm{O}+\mathrm{Al}_{2} \mathrm{O}_{3}(85: 15)$ & 0.73 & 0.59 \\
\hline $\mathrm{PVP}+\mathrm{MgCl}_{2} \cdot 6 \mathrm{H}_{2} \mathrm{O}+\mathrm{Al}_{2} \mathrm{O}_{3}(80: 20)$ & 0.04 & 0.23 \\
\hline
\end{tabular}
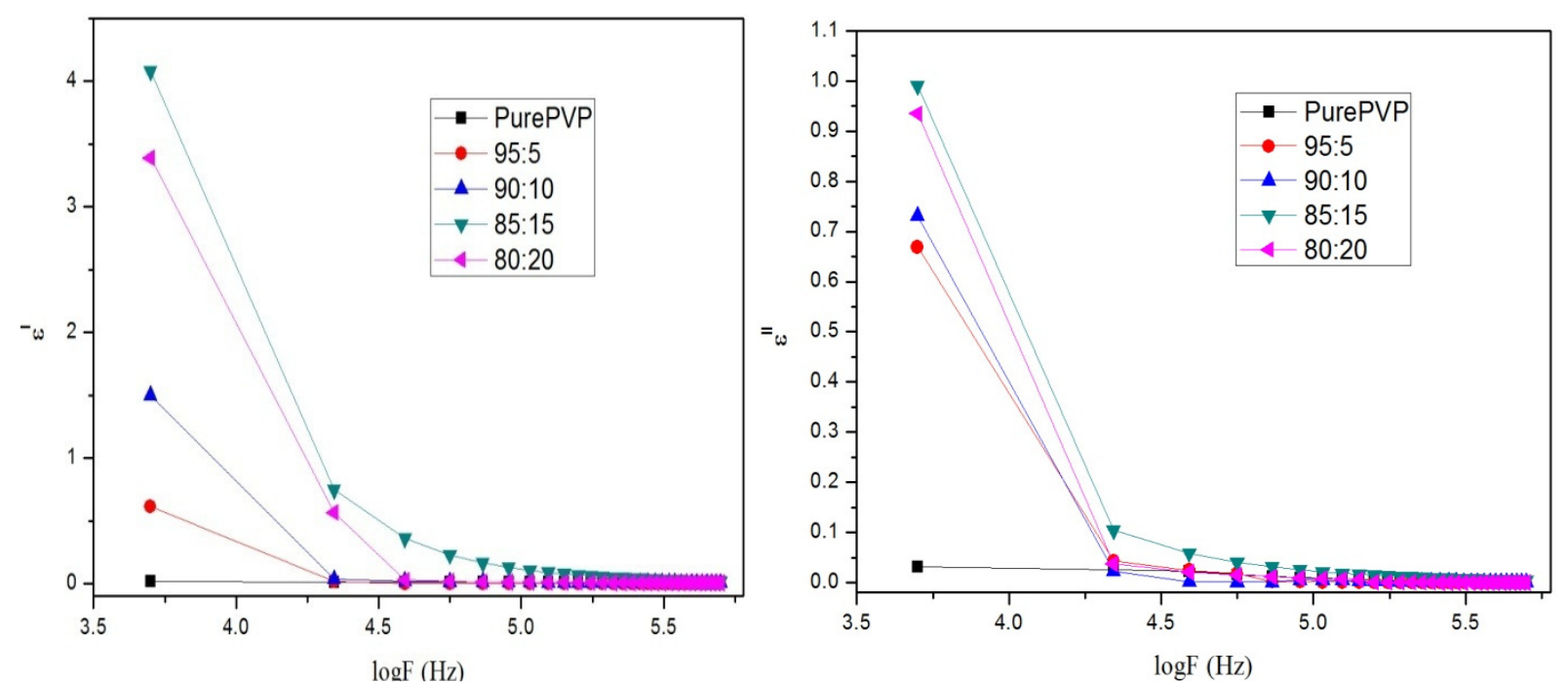

Fig. -3 and Fig.-4: Variation of $\log \mathrm{F}$ with dielectric permittivity for different wt $\%$ at $303 \mathrm{~K}$

Figure-5 shows the variation of tangent loss with frequency of polymer films for different concentrations of PVP at room temperature. The loss spectra characterized by peak appearing at a characteristic frequency for polymer samples suggest the relaxation dipole, the strength and frequency of relaxation depend on the characteristic property of dipole relaxation. The tangent loss peaks shift towards the higher frequency ${ }^{73}$.The small and mobile PVP speed up the segmental motion by increasing the available free volume. It is evident by the peak is shifted towards higher frequency side thereby reducing the relaxation time.

The dielectric constant of composite samples as a function of room temperature is shown in Figures- 6, 7 and 8. The dielectric constant of composite electrolytes increases apparently with the increase of temperature. The increment of dielectric constant peaks is observed at room temperature. The abrupt change in dielectric constant has been verified by the conductivity. This is due to the ionic jump orientation, space charge polarization and electronic contribution of $\mathrm{Mg}^{2+}$ ion. 
RASĀYAN J. Chem.

Vol. 10 | No. 1 |279 -285 | January - March | 2017

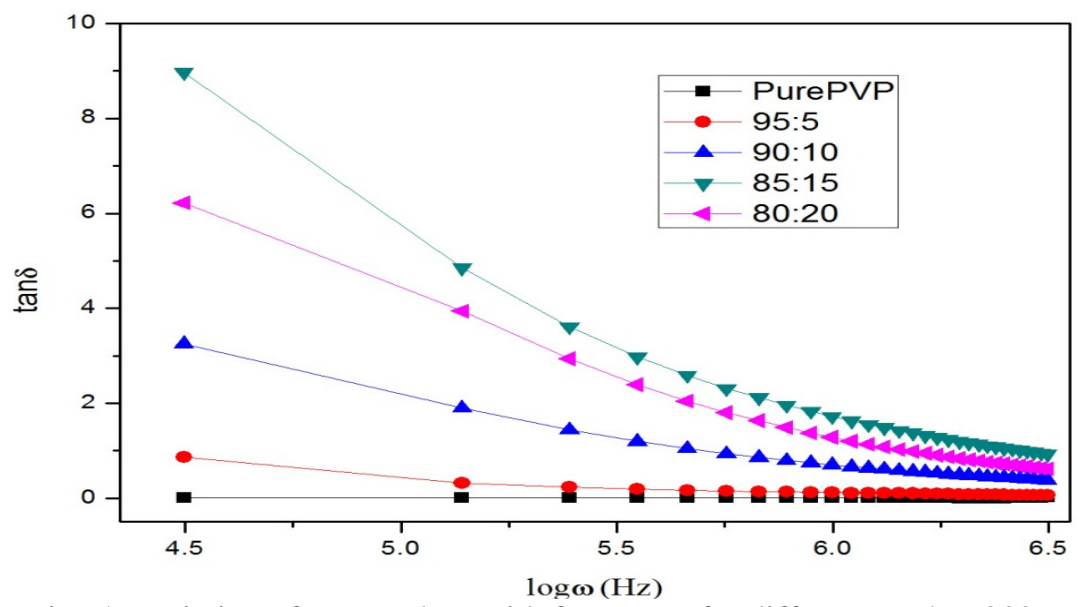

Fig.-5: Variation of tangent loss with frequency for different wt $\%$ at $303 \mathrm{~K}$

Figure-9 and Figure-10 show the variation of dielectric permittivity with the frequency for the PVP: $\mathrm{MgCl}_{2} \cdot 6 \mathrm{H}_{2} \mathrm{O}+\mathrm{Al}_{2} \mathrm{O}_{3}$, polymer electrolyte at room temperature. From the figures it is observed that as increasing the frequency the dielectric permittivity decreases monotonically and at higher frequency the dielectric values remain constant and the similar behavior is observed in reaming samples, which could be due to the dipole interaction and electrode-electrolyte polarization effects. At higher frequencies, the ionic diffusion doesn't takes place in the direction of the field.

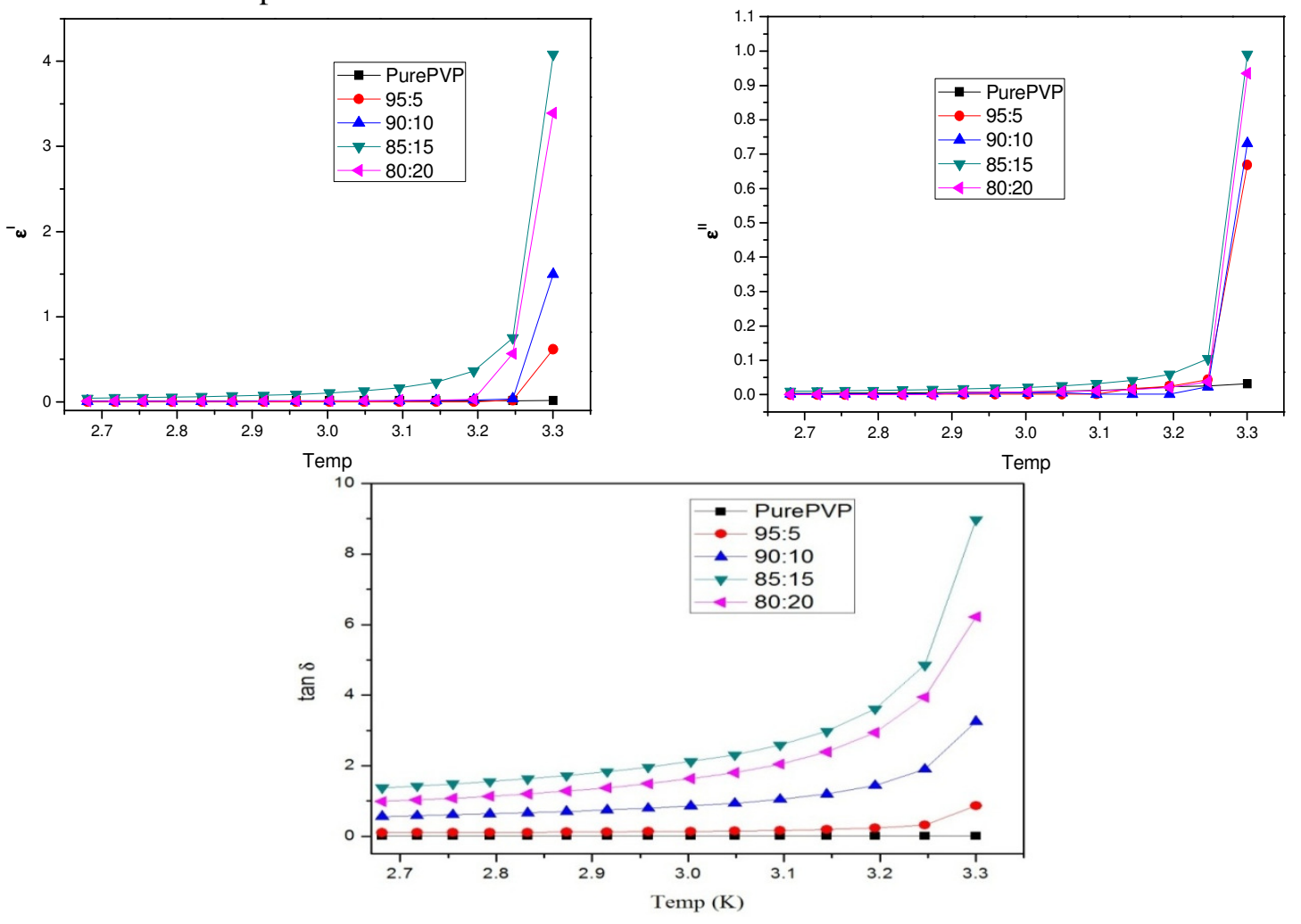

Fig. - $-6,7$ and 8: Variation of temperature with dielectric permittivity and tan $\delta$ for different wt $\%$ at $303 \mathrm{~K}$

\section{CONCLUSION}

Solid state polymer electrolyte of $\mathrm{Mg}^{2+}$ was prepared by PVP complexed with $\mathrm{MgCl}_{2} \cdot 6 \mathrm{H}_{2} \mathrm{O}+\mathrm{Al}_{2} \mathrm{O}_{3}$ by solution casting technique. From the conductivity studies the highest conductivity for PVP: $\mathrm{MgCl}_{2} \cdot 6 \mathrm{H}_{2} \mathrm{O}$ 
RASĀYAN $J$. Chem.

Vol. 10 | No. 1 |279-285 | January - March | 2017

$+\mathrm{Al}_{2} \mathrm{O}_{3}(85: 15)$ was found to be $1.22 \times 10^{-6}(\mathrm{~S} / \mathrm{cm})$ at room temperature which reveals that the high ionic conductivity composition film has the lowest activation energy. By using these polymer electrolyte films a solid state battery has been fabricated and their discharge characteristics were studied.
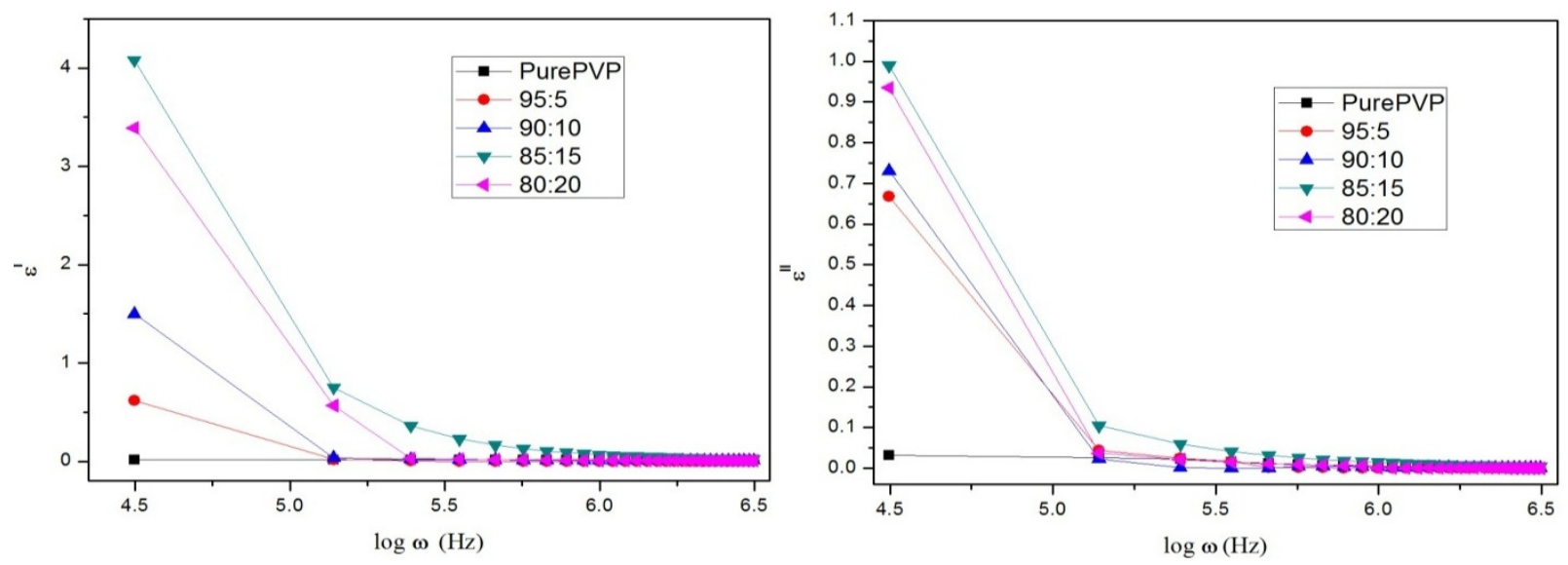

Fig.-9 and Fig.-10: Variation of dielectric permittivity with the frequency for different wt $\%$ at $303 \mathrm{~K}$

\section{REFERENCES}

1. M. Jaipal Reddy, J. Siva Kumar, U. V. Subba Rao and P. P. Chu, Solid State Ionics, 177, 253 (2006).

2. K. Naresh Kumar, T. Sreekanth, M. Jaipal Reddy and U.V. Subba Rao, J. Power Sources, 101, 130 (2001).

3. K. Murata, Electrochem. Acta, 40, 2177 (1995).

4. X. F. Yang, G. C. Wang, R. Y. Wang, X. W. Li, Electrochem. Acta, 55, 5414 (2010).

5. G. Sunita Sundari, K. Vijaya Kumar and Sk. Shahenoor Basha, Int.J.ChemTechRes., 9, 624 (2016).

6. D. E. Fenton, J. M. Parker, P. V. Wright, Polymer, 14, 589 (1973).

7. P.V. Wright, J. Polymer, 7, 319 (1975).

8. A.R. Polu, R. Kumar,Int. J. Polym. Mater., 62, 76 (2012).

9. M. B. Armand, Solid State Ionics, 9,745 (1983).

10. M.C. Rao, O.M. Hussain,J. Alloys Compd,491, 503 (2010).

11. T.D. Gregory, R.J. Hoffmann, R.C. Winterton, J. Electrochem. Soc., 137, 775 (1990).

12. E.M. Abdelrazeka, H. M. Ragabb, M. Abdelaziz, Polymer Tech., 2, 1 (2013).

13. Sk. Shahenoor Basha, G. Sunita Sundari, K. Vijaya Kumar, M.C. Rao, Rasayan J.Chem.,9, 348 (2016).

14. Sk. Shahenoor Basha, G. Sunita Sundari, K. Vijaya Kumar, Int.J.ChemTechRes., 8, 803(2015).

15. M.C. Rao, O.M. Hussain, J. Alloys Compd., 491(1), 503 (2010).

16. M.C. Rao, J. Crys. Growth, 312(19), 2799 (2010).

17. M.C. Rao, K. Ramachandra Rao, Int. J. Chem.Tech Res., 6(7), 3931 (2014).

18. M.C. Rao, Optoelect. \& Adv. Mater (Rapid Commu.), 5, 85 (2011).

19. Sk. Muntaz Begum, M.C. Rao and R.V.S.S.N. Ravikumar, Spectrochim. Acta Part A: Mol. \& Biomol. Spec., 98, 100 (2012).

20. M.C. Rao, J. Optoelect. \& Adv. Mater., 13, 428 (2011).

21. M.C. Rao, O.M. Hussain, Eur. Phys. J. Appl. Phys., 48(2), 20503 (2009).

22. Sk. Muntaz Begum, M.C. Rao and R.V.S.S.N. Ravikumar, J. Inorg. Organometa. Poly. Mater., 23(2), 350 (2013).

23. MC Rao, J. Optoelect. \& Adv. Mater., 12, 2433 (2010).

24. M.C. Rao, O.M. Hussain, IOP Conf. Series: Mater. Sci. Eng., 2, 012037, (2009).

25. M.C. Rao, O. M. Hussain, Ind. J. Eng. Mater. Sci., 16, 335 (2009).

26. M.C. Rao, Optoelect. \& Adv. Mater. (Rapid Commu.), 5(5-6), 651 (2011).

27. M.C. Rao, O.M. Hussain, Optoelect. \& Adv. Mater., 13(2-4), 1109 (2011). 
RASĀYAN $J$. Chem.

Vol. 10 | No. 1 |279-285 | January - March | 2017

28. MC Rao, J. Optoelect. Adv. Mater., 13(1-2), 72 (2011).

29. MC Rao, OM Hussain, Res. J. Chem. Sci., 1(7), 92 (2011).

30. M.C. Rao, Int. J. Chem. Sci., 10(2), 1111 (2012).

31. M.C. Rao, Optoelect. \& Adv. Mater. (Rapid Commu.), 6, 511 (2012).

32. P.V. Prasad, K. Ramachandra Rao, M.C. Rao, J. Mol. Struc., 1085, 115 (2015).

33. M.C. Rao, J. Optoelect. \& Adv. Mater., 13, 78 (2011).

34. M.C. Rao, Sk. Muntaz Begum, Optoelect. \& Adv. Mater. (Rapid Commu.), 6, 508 (2012).

35. MC Rao, Res. J. Rec. Sci., 2(3), 67 (2013).

36. K. Parameswara Rao, G.V. Ramana, M.C. Rao, Der Pharm. Lett., 8(10), 222 (2016).

37. M.C. Rao, Int. J. Chem. Tech. Res., 6(3), 1904 (2014).

38. M.C. Rao, Optoelect. \& Adv. Mater. (Rapid Commu.), 4, 2088 (2010).

39. M.C. Rao, O. M. Hussain, Optoelect. \& Adv. Mater. (Rapid Commu.), 6, 245 (2012).

40. M.C. Rao, K. Ravindranadh, Der Phar. Chem., 8, 243 (2016).

41. M.C. Rao, Res. J. Rec. Sci., 2 (3), 67 (2013).

42. M.C. Rao, K. Ravindranadh, A. Kasturi, M.S. Shekhawat, Res. J. Rec. Sci., 2(4), 1 (2013).

43. K. Parameswara Rao, G.M. Srirangam, G.V. Ramana and M.C. Rao, Rasayan J. Chem., 9(3), 393 (2016)

44. M.C. Rao, O.M. Hussain, Res. J. Chem. Sci., 1(7), 76 (2011).

45. M.C. Rao, J. Non-Oxide Glasses, 5, 1 (2013).

46. Sk. Muntaz Begum, K. Ravindranadh, M.C. Rao, R.V.S.S.N. Ravikumar, AIP Conf. Proc., 1536, 27 (2013).

47. M.C. Rao, AIP Conf. Proc., 1728 (1), 020077 (2016).

48. K. Ravindranadh, M.C. Rao, AIP Conf. Proc., 1728 (1), 020079 (2016).

49. K. Ravindranadh, M.C. Rao, AIP Conf. Proc., 1536 (1), 219 (2016).

50. M.C. Rao, AIP Conf. Proc., 1536 (1), 215 (2016).

51. M.C. Rao, Optoelect. \& Adv. Mater. (Rapid Commu.), 6, 245 (2012).

52. K. Sivaram, M.C. Rao, Rasayan J. Chem., 10 (1), 69 (2017).

53. K. Sivaram, M.C. Rao, Rasayan J. Chem., 10 (1), 16 (2017).

54. Sk. Shahenoor Basha, M.C. Rao, J. Inorg. Organomet. Polym. Mater., 27, 455 (2017).

55. M.C. Rao, Optoelect. \& Adv. Mater. (Rapid Commu.), 10, 889 (2016).

56. M. Tejaswi, M.C. Rao, Rasayan J. Chem., 9(4), 697 (2016).

57. P. Jayaprada, M.C. Rao, Rasayan J. Chem., 9(4), 588 (2016).

58. J. Sivasri, M.C. Rao, Rasayan J. Chem., 9(4), 556 (2016).

59. P.V. Prasad, K. Ramachandra Rao, M.C. Rao, Int. J. Chem Tech Res. 7(1), 269 (2014).

60. S. Rajyalakshmi, K. Ramachandra Rao, M.C. Rao, Int. J. ChemTech Res., 9(1), 7 (2016).

61. T. Samuel, K. Ramachandra Rao, M.C. Rao, AIP Conf. Proc., 1728 (1), 020080 (2016).

62. M.C. Rao, Int. J. Pure Appl. Phys., 6, 365 (2010).

63. K. Parameswara Rao, G.V. Ramana and M.C. Rao, Der Pharm. Lett., 8(14), 132 (2016).

64. K. Parameswara Rao and M.C. Rao, Der Pharm. Lett., 8(15), 125 (2016).

65. M.C. Rao, Sk. Muntaz Begum, AIP Conf. Proc., 1447, 613 (2012).

66. K. Ravindranadh, M.C. Rao, Int. J. ChemTech Res., 9(4), 598 (2016).

67. M.C. Rao, AIP Conf. Proc., 1447, 613 (2012).

68. M.C. Rao, AIP Conf. Proc., 1536, 27 (2013).

69. C.W. Liew, S. Ramesh, J. Mater. Res., 27, 2996 (2012).

70. S. Rajendran, R. SankarBabu, P. Siva Kumar, J. Membrane Sci.,315,67 (2008).

71. D. Ravinder, A. V. Ramana Reddy, G.Ranga Mohan, Mater. Lett., 52, 259(2002).

72. A. Chandra, R.C. Agrawal, Y.K. Mahipal, J. Phys. D. Appl. Phys.,42,1(2009).

73. N. Shukla, K. Awalendra, A. Shukla, T. David, Int. J. Electrochem. Sci., 9, 7644 (2014).

[RJC-1612/2017] 